Review

\title{
Maize Prolamins Could Induce a Gluten-Like Cellular Immune Response in Some Celiac Disease Patients
}

\author{
Juan P. Ortiz-Sánchez ${ }^{1}$, Francisco Cabrera-Chávez ${ }^{2}$ and Ana M. Calderón de la Barca ${ }^{1, *}$ \\ 1 Department of Nutrition, Research Center for Food and Development (CIAD, A.C.), \\ Carr. La Victoria, Km. 0.6, Hermosillo, Sonora 83304, Mexico; E-Mail: juanpedroo@gmail.com \\ 2 Nutrition Sciences and Gastronomy Unit, University of Sinaloa, Culiacan, Sinaloa 80019, Mexico; \\ E-Mail: fcabrera@uas.edu.mx
}

* Author to whom correspondence should be addressed; E-Mail: amc@ciad.mx; Tel.: +52-662-289-2400 (ext. 288); Fax: +52-662-280-0094.

Received: 1 August 2013; in revised form: 2 October 2013 / Accepted: 10 October 2013 / Published: 21 October 2013

\begin{abstract}
Celiac disease (CD) is an autoimmune-mediated enteropathy triggered by dietary gluten in genetically prone individuals. The current treatment for $\mathrm{CD}$ is a strict lifelong gluten-free diet. However, in some CD patients following a strict gluten-free diet, the symptoms do not remit. These cases may be refractory $\mathrm{CD}$ or due to gluten contamination; however, the lack of response could be related to other dietary ingredients, such as maize, which is one of the most common alternatives to wheat used in the gluten-free diet. In some CD patients, as a rare event, peptides from maize prolamins could induce a celiac-like immune response by similar or alternative pathogenic mechanisms to those used by wheat gluten peptides. This is supported by several shared features between wheat and maize prolamins and by some experimental results. Given that gluten peptides induce an immune response of the intestinal mucosa both in vivo and in vitro, peptides from maize prolamins could also be tested to determine whether they also induce a cellular immune response. Hypothetically, maize prolamins could be harmful for a very limited subgroup of CD patients, especially those that are non-responsive, and if it is confirmed, they should follow, in addition to a gluten-free, a maize-free diet.
\end{abstract}

Keywords: celiac disease; cellular immune response; maize prolamins; zeins 


\section{Introduction}

Celiac disease (CD) is an immune-mediated enteropathy triggered by dietary wheat, rye and barley gluten (water-insoluble proteins) in genetically predisposed individuals [1]. Characteristic features of CD involve crypt hyperplasia, intra-epithelial lymphocytosis and villus atrophy of the intestinal mucosa. These injuries affect intestinal function and nutrient absorption, which can cause a variety of gastrointestinal and extra-intestinal symptoms [2].

Intestinal mucosa damage in CD patients begins with an innate response that leads to a cellular immune response [3]. First, prolamin peptides from gluten, which are resistant to human digestion, interact with a chemokine receptor, inducing zonulin release and a subsequent tight junction disassembly [4]. Then, the damaged barrier allows the arrival of gliadin peptides to the lamina propria, where tissue transglutaminase (tTG) deamidates specific glutamine residues to confer an overall negative charge. These peptides are bound to the human leucocyte antigen (HLA) DQ2 or DQ8 molecules, in antigen presenting cells, which present them to T-cells to develop the full immune response required for $\mathrm{CD}$ [5]. In addition to gluten peptides, self tTG is presented to T-cells, which triggers an auto-immune response. Therefore, $\mathrm{CD}$ is considered an autoimmune disease.

CD symptoms disappear in the majority of patients after dietary gluten withdrawal; however, in some patients, the symptoms are still present even after they adopt a strict gluten-free diet [6]. This is due to either refractory $\mathrm{CD}$ or to the presence of gluten as a contaminant or as a non-declared additive in foods [7]. Additionally, the lack of response to dietary gluten withdrawal in a very limited subgroup of patients, could be due to other dietary proteins present in the gluten-free diet, such as those from maize, which is a common alternative ingredient used in gluten-free diets.

It has been demonstrated that zeins, the maize prolamins, are able to induce an inflammatory response through contact with the mucosa in some CD patients [8]. Furthermore, IgA antibodies from some CD patients can recognize zeins [9], even after lime and/or enzymatic treatments [10]. Perhaps, in active $\mathrm{CD}$, peptides derived from zeins could exacerbate the immune response in the intestinal mucosa, because they have sequence characteristics and/or electronegative residues that resemble gluten peptides.

\section{Supporting Experimental Results}

Table 1 summarizes the similarities between maize prolamin peptides and wheat celiac-toxic gluten peptides that are involved in the pathogenesis of celiac disease. These results support the hypothesis that peptides from zeins that are resistant to human digestion are able to induce a celiac-like immune response in some $\mathrm{CD}$ patients by a similar mechanism to that triggered by wheat gluten peptides.

\subsection{Incomplete Protein Digestion}

Pepsin and trypsin, the main peptidases of the intestinal tract, cannot completely digest wheat gluten, because they are unable to cut its $15 \%$ proline-containing polypeptides $[11,12]$. The result is the release of peptides larger than nine amino acids, which are capable of eliciting innate and adaptive immune responses [13]. The proline content of zeins is also high (9\%) and, although zeins contain bonds that pepsin can cut, they also contain cysteine residues with disulfide bonds that obstruct 
digestion by pepsin [14]. All together, the ability of trypsin to digest zeins is low due to their low number of cleavage sites, low solubility [15] and secondary conformation [16].

Table 1. Similarities between maize prolamin peptides and wheat celiac-toxic gluten peptides that are involved in the pathogenesis of celiac disease (CD). NO: nitric oxide; NOS: nitric oxide synthase; HLA-DQ2 or DQ8: human leucocyte antigen molecules; IFN- $\gamma$ : interferon gamma.

\begin{tabular}{|c|c|c|}
\hline $\begin{array}{c}\text { Step in CD } \\
\text { Pathogenesis }\end{array}$ & $\begin{array}{l}\text { Characteristics of Celiac-Toxic Peptides from } \\
\text { Wheat Gluten }\end{array}$ & $\begin{array}{c}\text { Characteristics of Maize Prolamins That } \\
\text { Could be Inducers for CD }\end{array}$ \\
\hline $\begin{array}{l}\text { Incomplete protein } \\
\text { digestion }\end{array}$ & $\begin{array}{l}\text { Gastrointestinal peptidases do not digest the } \\
\text { proline-rich wheat gluten polypeptides completely, } \\
\text { which releases peptides larger than nine } \\
\text { amino acids [11,12]. }\end{array}$ & $\begin{array}{l}\text { Digestion of zeins is poor due to relatively } \\
\text { high concentrations of glutamine, proline } \\
\text { and cysteine residues [14-16]. }\end{array}$ \\
\hline $\begin{array}{l}\text { Innate immune } \\
\text { response }\end{array}$ & $\begin{array}{l}\text { Increased levels of NO were produced by } \\
\text { challenged granulocytes and NOS expression was } \\
\text { increased in enterocytes from CD patients' small } \\
\text { intestine biopsies }[17,18] \text {. }\end{array}$ & $\begin{array}{l}\text { Proteins from maize caused granulocyte } \\
\text { activation in a rectal challenge in six out of } \\
13 \text { CD patients tested [8]. }\end{array}$ \\
\hline $\begin{array}{l}\text { Adaptive immune } \\
\text { response: } \\
\text { deamidation of } \\
\text { peptides by tTG }\end{array}$ & $\begin{array}{l}\text { Gluten peptides deamidated by tTG in the lamina } \\
\text { propria contain negative charges [19-21]. }\end{array}$ & $\begin{array}{l}\text { Maize prolamins deamidated by } \mathrm{TG} \\
\text { in vitro were better recognized than native } \\
\text { ones by IgA from some CD } \\
\text { patients' sera [22]. }\end{array}$ \\
\hline $\begin{array}{l}\text { Adaptive response: } \\
\text { increased affinity of } \\
\text { HLA-DQ2/DQ8 on } \\
\text { antigen presenting } \\
\text { cells to bind } \\
\text { peptides }\end{array}$ & $\begin{array}{l}\text { HLA-DQ2 prefers negatively charged amino } \\
\text { acids from gluten peptides at the p4, p6 or p7 } \\
\text { positions in the peptide, while HLA-DQ } 8 \text { prefers } \\
\text { them at positions p1 or p9 [20]. }\end{array}$ & $\begin{array}{l}\text { Peptides from digested maize prolamins } \\
\text { have glutamine at positions p1 and p9 that } \\
\text { can be deamidated by tTG and bind to } \\
\text { HLA-DQ8 }[23,24] \text {. Other peptides can be } \\
\text { bound by HLA-DQ2 [10]. }\end{array}$ \\
\hline $\begin{array}{l}\text { Adaptive response: } \\
\text { processing and } \\
\text { presentation of } \\
\text { peptides }\end{array}$ & $\begin{array}{l}\text { After processing, the deamidated gluten peptides } \\
\text { are presented to T-cells. Then, B-cells are induced } \\
\text { to proliferate and produce } \\
\text { antibodies [25]. }\end{array}$ & $\begin{array}{l}\text { T-cells from the intestine of one out of seven } \\
\text { CD patients stimulated by maize prolamins } \\
\text { and teff produced low IFN- } \gamma \text { as compared to } \\
\text { wheat, but higher than control and other } \\
\text { non-wheat grains [26]. Additionally, IgA } \\
\text { antibodies against maize prolamins were } \\
\text { detected in several CD patients }[10,27] \text {. }\end{array}$ \\
\hline $\begin{array}{l}\text { Adaptive response: } \\
\text { role of antibodies } \\
\text { against dietary } \\
\text { prolamins }\end{array}$ & $\begin{array}{l}\text { Roles of tTG-specific antibodies induced by gluten } \\
\text { in CD patients could be: inhibiting epithelial cell } \\
\text { differentiation and inducing their proliferation, } \\
\text { increasing epithelial and blood vessel permeability } \\
\text { and affecting angiogenesis [28]. }\end{array}$ & $\begin{array}{l}\text { Although the levels of antibodies against } \\
\text { gluten decrease in some CD patients } \\
\text { following a gluten-free diet, antibodies } \\
\text { against maize prolamins remained high } \\
\text { until both gluten and maize were } \\
\text { avoided }[29,30] \text {. }\end{array}$ \\
\hline $\begin{array}{l}\text { Adaptive response: } \\
\text { activation of T-cells }\end{array}$ & $\begin{array}{l}\text { Activated T-cells drive the inflammatory response } \\
\text { that leads to the development of the characteristic } \\
\text { celiac lesions and the symptoms [31]. T-cells } \\
\text { induce damage mostly by IFN- } \gamma \text { production [32]. }\end{array}$ & $\begin{array}{l}\text { Neither the intestinal lesions nor the CD } \\
\text { symptoms were alleviated with a } \\
\text { gluten-free diet when maize was } \\
\text { still eaten [29]. }\end{array}$ \\
\hline
\end{tabular}




\subsection{The Inflammatory Process}

Nitric oxide (NO) production is involved in the innate inflammatory response mediated by macrophages in $\mathrm{CD}$, and it has been detected in cultured gluten-challenged small intestine biopsies [17]. Additionally, there is an elevated expression of mRNA encoding the major inducible isoform of NO synthase II (iNOS) in untreated CD patients [18]. After rectal wheat gluten challenge in CD patients, granulocyte activation precedes NO production. Furthermore, some patients have been found to display signs of a similar inflammatory reaction after challenge with maize prolamins [8].

\subsection{Deamidation of the Peptides}

Gluten peptides are transported across the epithelial barrier to the lamina propria, where tTG changes the glutamine residues to glutamic acid. Antigen-presenting cells then process these negatively charged peptides and increase their affinity for the major histocompatibility complex (MHC) class II molecules, HLA-DQ2 and HLA-DQ8. These immunogenic peptide fragments can stimulate HLA-DQ2- and HLA-DQ8-restricted T-cells and trigger an adaptive response in the lamina propria [19-21]. Maize prolamins likely are also deamidated by tTG, because IgA from CD patients was more immunoreactive against maize prolamins extracted from maize bread, treated with microbial transglutaminase, than against maize prolamins from untreated bread [22].

\subsection{Affinity of HLA/DQ8 Molecules to Bind Peptides}

Adaptive responses to gluten initiate when dendritic cells phagocytose gliadin peptides and present them to undifferentiated $\mathrm{T}$ helper cells, whose activation is crucial for the development of $\mathrm{CD}$. Peptide deamidation by tTG increases the affinity of HLA-DQ2/DQ8 for these peptides. HLA-DQ2 has an affinity for negatively charged amino acids at the p4, p6 or p7 positions in the peptide, while HLA-DQ8 has an affinity for those residues at positions p1 and p9 [23]. The primary amino acid sequences of maize zeins can fit into these HLA binding sites once they are deamidated. Through in silico analysis, Darewicz et al. [24] identified a high degree of homology between two zein peptides and the celiac-toxic peptides from prolamins found in wheat, barley and rye (gliadins, hordeins and secalins, respectively). Moreover, we have identified a peptide sequence ( $\alpha$-zein 58-91) that is resistant to complete digestion and which has characteristics that would allow it to bind to HLA-DQ8 [10]. In addition to this peptide, Table 2 provides the sequence of a 33-mer ( $\alpha 2$-gliadin 56-88) peptide that is a potent T-cell stimulator [19].

Table 2. Theoretical peptide sequences that bind to HLA-DQ2/DQ8 molecules. After deamidation by tTG [33], glutamine residues (underlined) became glutamic acid, which is an electronegative residue that binds to $\mathrm{p} 4$ and 6 in HLA-DQ2 and $\mathrm{p} 1$ and 9 in HLA-DQ8.

\begin{tabular}{ccccc}
\hline Food & Peptide & Sequence & Affinity & Reference \\
\hline Wheat & $\alpha$-Gliadin & LQLQPFPQPQLPYPQPQLPYPQPQLPYPQPQPF & HLA-DQ2 & {$[19]$} \\
Wheat & $\alpha$ Gliadin & LQLQPFPQPQLPYPQPQLPYPQPQLPYPQPQPF & HLA-DQ8 & {$[19]$} \\
Maize & $\alpha$-Zein & LQQAIAASNIPLSPLLFQQSPALSLVQSLVQTIR & HLA-DQ8 & {$[10]$} \\
\hline
\end{tabular}




\subsection{Processing and Presentation of Peptides}

Peptides of gliadin are deamidated by tTG, phagocytosed, processed and transported to the cell surface in dendritic cells via MHC class II molecules. Subsequently, the peptides are presented to infiltrated $\mathrm{T}$ helper cells that recognize deamidated peptides and trigger the proliferation of specific B-cells and the production of IgA anti-gliadin and anti-transglutaminase antibodies [25]. Some celiac patients contain B-cells that produce anti-maize prolamin IgA antibodies that do not cross-react with anti-wheat prolamins [10,27].

\subsection{Role of Antibodies}

After the DQ2-/DQ8-dependent activation of CD4+ T-cells, B-cells are stimulated and produce auto-antibodies. These auto-antibodies in the intestinal lumen could be involved in disease pathogenesis in various ways. For instance, they could be involved in inhibiting epithelial cell differentiation, augmenting epithelial cell proliferation, increasing epithelial and blood vessel permeability and affecting angiogenesis [28]. In some CD patients on a gluten-free diet, including maize-based foods, the anti-gliadin and anti-tTG antibody titers diminished, but the symptoms persisted [29,30]. Total symptom remission in these cases was achieved only with a gluten- and maize-free diet [30]. It is possible that partial production of anti-tTG antibodies, in addition to anti-zein antibodies, continued to affect the intestinal mucosa when dietary maize was present.

\subsection{Activation of T-Cells}

The activation of gliadin-reactive CD4+ T-cells results in the production of cytokines that drive an inflammatory response, which leads to the development of the characteristic CD lesions and symptoms [31]. Gluten-specific T-cells induce tissue damage mostly by the production of interferon (IFN)- $\gamma$ [32]. There is some evidence of T-cells being simulated by maize prolamins: intestinal T-cells cultured from CD patients were challenged with maize prolamins in vitro, and T-cells from one out of seven samples produced IFN- $\gamma$ as a result of T-cell stimulation [26]. Although this patient response was not specific, maize and teff peptides produced higher levels of IFN- $\gamma(145.6$ and $154.4 \mathrm{pg} / \mathrm{mL}$, respectively) than the negative control $(10.9 \mathrm{pg} / \mathrm{mL})$ and others "non-toxic" grains $(\approx 110 \mathrm{pg} / \mathrm{mL})$.

Dietary gluten withdrawal has been demonstrated to induce mucosal recovery and the disappearance of CD symptoms. Nevertheless, some patients on gluten-free diet have forms of CD that do not respond to this diet. This could be due to a higher sensibility of these patients to "gluten-free" foods that still contain some traces of gluten [34] or to the presence of other cereal prolamins, such as those in maize in a very limited subgroup of CD patients.

\section{Potential Links between Zeins and CD}

Based on the similarities between wheat and maize prolamins discussed above, we can infer that the innate and adaptive responses to zeins would be similar to the response against gliadins in CD patients. Nevertheless, it is necessary to identify whether zeins contain immunodominant and minor epitopes similar to those found in gliadins after proteolysis. Some authors have found that there is no effect on T-cell activation or pro-inflammatory cytokine secretion when CD patient biopsies were treated with 
whole pepsin-trypsin digested prolamins from maize [26,35]. Therefore, there is a need to evaluate the effect of isolated immunogenic peptides from maize prolamins, which can be obtained by in silico analysis [10].

The evaluation of the response of immune cells to gliadins includes the increased expression of surface receptors and the production of different cytokines for both tissue and immune cells. Some of these receptors include HLA-DR (human leucocyte antigen), CD54 or ICAM-1 (intercellular adhesion molecule), CD3 (in mature T-cells), CD25 (interleukin-2 receptor) and CD69 (in activated T-cells and natural killer cells) $[36,37]$. Cytokines that would be produced include interferon gamma, interleukins (IL) 2 and 15 and zonulin [13,38-40]. To evaluate the immune response, an analysis of the protein expression of these markers can be performed after CD patient biopsies are challenged with zein peptides. These ex vivo digested-peptide challenge analyses are considered useful tools to evaluate the safety of non-gluten prolamins in a gluten-free diet $[26,40]$.

There is evidence that after a short gluten challenge in treated CD patients, gluten-specific T-cells are present in peripheral blood [41-44]. After this in vivo challenge, peripheral blood mononuclear cells can be isolated and activated with gluten peptides for quantitative detection of pro-inflammatory cytokines and direct detection of HLA-DQ2 tetramer specific for gliadins. For both cytokine measurements and the detection of an immune response, these techniques would be very useful in the evaluation of the effect of maize prolamins on the immune response in CD patients.

\section{Conclusions}

Although reaction to maize prolamins in CD patients appears to be a rare event, the confirmation that they play a role in the pathogenesis of $\mathrm{CD}$ will be useful information for the follow-up of some non-responsive celiac patients. It is estimated that approximately $10 \%$ to $18 \%$ of these cases are refractory $\mathrm{CD}$, which represents a more severe $\mathrm{CD}$, with a clear malignity and a less favorable prognosis [7]. Therefore, it is important to assess these clinical cases, because uncontrolled CD can lead to several malabsorption problems, osteoporosis and other autoimmune diseases [45].

Maize is one of the most commonly consumed grains in the gluten-free diet. Despite the low content of zeins in maize-containing foods compared with that of gliadins in wheat-containing foods, maize could be responsible for persistent mucosal damage in a very limited subgroup of CD patients. If our hypothesis is proven, zeins could be classified as harmful for some CD patients, especially those showing a poor response to a gluten-free diet.

\section{Acknowledgments}

Financial support was from the Mexican Conacyt (grant CB-2008-01-106227) and Ph.D. fellowship for J.P. Ortiz-Sanchez (101386). Authors are grateful to V. Mata-Haro, R. Sotelo-Mundo and M.I. Ortega for comments on the manuscript and to M.Sci. A. Bolaños for editing assistance.

\section{Conflicts of Interest}

The authors declare no conflict of interest. 


\section{References}

1. Ludvigsson, J.F.; Leffler, D.A.; Bai, J.C.; Biagi, F.; Fasano, A.; Green, P.H.R.; Hadjivassiliou, M.; Kaukinen, K.; Kelly, C.P.; Leonard, J.N.; et al. The Oslo definitions for celiac disease and related terms. Gut 2012, 62, 43-52.

2. Husby, S.; Koletzko, S.; Korponay-Szabó, I.R.; Miarin, M.L.; Phillips, A.; Shamir, R.; Troncone, R.; Giersiepen, K.; Branski, D.; Catassi, C.; et al. European Society for Pediatric Gastroenterology, Hepatology, and Nutrition guidelines for the diagnosis of coeliac disease. J. Pediatr. Gastroenterol. Nutr. 2012, 54, 136-160.

3. Abadie, V.; Sollid, L.M.; Barreiro, L.B.; Jabri, B. Integration of genetic and immunological insights into a model of celiac disease pathogenesis. Annu. Rev. Immunol. 2011, 29, 493-525.

4. Lammers, K.M.; Lu, R.; Brownley, J.; Lu, B.; Gerard, C.; Thomas, K.; Rallabhandi, P.; Shea-Donohue, T.; Tamiz, A.; Alkan, S.; et al. Gliadin induces an increase in intestinal permeability and zonulin release by binding to the chemokine receptor CXCR3. Gastroenterology 2008, 135, 194-204.

5. Sollid, L.M.; Qiao, S.W.; Anderson, R.P.; Gianfrani, C.; Koning, F. Nomenclature and listing of celiac disease relevant gluten T-cell epitopes restricted by HLA-DQ molecules. Immunogenetics 2012, 64, 455-460.

6. Lanzini, A.; Lanzarotto, F.; Villanacci, V.; Mora, A.; Bertolazzi, S.; Turini, D.; Carella, G.; Malagoli, A.; Ferrante, G.; Cesana, B.M.; et al. Complete recovery of intstinal mucosa occurs very rarely in adult celiac patients despite adherence to gluten-free diet. Aliment. Pharmacol. Ther. 2009, 29, 1299-1308.

7. Rubio-Tapia, A.; Murray, J.A. Classification and management of refractory celiac disease. Gut 2010, 59, 547-557.

8. Kristjansson, G.; Högman, M.; Venge, P.; Hällgren, R. Gut mucosal granulocyte activation precedes nitric oxide production: Studies in celiac patients challenged with gluten and corn. Gut 2005, 54, 769-774.

9. Cabrera-Chávez, F.; Rouzaud-Sánchez, O.; Sotelo-Cruz, N.; Calderón de la Barca, A.M. Bovine milk caseins and transglutaminase-treated cereal prolamins are differentially recognized by IgA of celiac disease patients according to their age. J. Agric. Food Chem. 2009, 57, 3754-3759.

10. Cabrera-Chávez, F.; Iameti, S.; Miriani, M.; Calderón de la Barca, A.M.; Mamone, G.; Bonomi, F. Maize prolamins resistant to peptic-tryptic digestion maintain immune-recognition by IgA from some celiac disease patients. Plant Food Hum. Nutr. 2012, 67, 24-30.

11. Shan, L.; Molberg, O.; Parrot, I.; Hausch, F.; Filiz, F.; Gray, G.; Sollid, L.; Khosla, C. Structural basis for gluten intolerance in celiac sprue. Science 2002, 297, 2275-2279.

12. Hausch, F.; Shan, L.; Santiago, N.; Gray, G.; Khosla, C. Intestinal digestive resistance of immunodominant gliadin peptides. Am. J. Physiol. Gastrointest. Liver Physiol. 2002, 283, G996-G1003.

13. Bernardo, D.; Garrote, J.A.; Fernández-Salazar, L.; Riestra, S. Is gliadin really safe for non-coeliac individuals? Production of interleukin 15 in biopsy culture from non-coeliac individuals challenged with gliadin peptides. Gut 2007, 56, 889-890. 
14. Shukla, R.; Cheryan, M. Zein: The industrial protein from corn. Ind. Crop. Prod. 2001, 13, 171-192.

15. Tschiersch, C.; Nikfardjam, M.P.; Schmidt, O.; Schwack, W. Degree of hydrolysis of some vegetable proteins used as fining agents and its influence on polyphenol removal from red wine. Eur. Food Res. Technol. 2010, 231, 65-74.

16. Zhang, B.; Luo, Y.; Wang, Q. Effect of acid and base treatments on structural, rheological, and antioxidant properties of $\alpha$-zein. Food Chem. 2011, 124, 210-220.

17. Beckett, C.G.; Dell'Olio, D.; Shidrawi, R.G.; Rosen-Bronson, S.; Ciclitira, P.J. Gluten-induced nitric oxide and pro-inflamatory citokine release by cultured coeliac small intestinal biopsies. Eur. J. Gastroenterol. Hepatol. 1999, 11, 529-536.

18. Daniels, I.; Cavill, D.; Murray, I.A.; Iargo, R.G. Elevated expression of iNOS mRNA and protein in celiac disease. Clin. Chim. Acta 2005, 356, 134-142.

19. Qiao, S.W.; Bergseng, E.; Molberg, O.; Xia, J.; Fleckenstein, B.; Khosla, C.; Sollid, L.M. Antigen presentation to celiac lesion-derivated $\mathrm{T}$ cells of a 33-mer gliadin peptide naturally formed by gastrointestinal digestion. J. Immunol. 2004, 173, 1757-1762.

20. Koning, F.; Gilissen, L.; Wijmenga, C. Gluten: A two-edged sword. Immunopathogenesis of celiac disease. Springer Semin. Immunopathol. 2005, 27, 217-232.

21. Ciccocioppo, R.; di Sabatino, A.; Corazza, G.R. The immune recognition of gluten in coeliac disease. Clin. Exp. Immunol. 2005, 140, 408-416.

22. Cabrera-Chávez, F.; Rouzaud-Sánchez, O.; Sotelo-Cruz, N.; Calderón de la Barca, A.M. Transglutaminase treatment of wheat and maize prolamins of bread increases the serum IgA reactivity of celiac disease patients. J. Agric. Food Chem. 2008, 56, 1387-1391.

23. Stepniak, D.; Wiesner, M.; de Ru, A.H.; Moustakas, A.K.; Drijfhout, J.W.; Papadopoulos, G.K.; van Veelen, P.A.; Koning, F. Large-scale characterization of natural ligands explains the unique gluten-binding properties of HLA-DQ2. J. Immunol. 2008, 180, 3268-3278.

24. Darewicz, M.; Dziuba, J.; Minkiewicz, P. Computational characterization and identification of peptides for in silico detection of potentially celiac-toxic proteins. Food Sci. Technol. Int. 2007, 13, 125-133.

25. Briani, C.; Samaroo, D.; Alaedini, A. Celiac disease: From gluten to autoimmunity. Autoimmun. Rev. 2008, 7, 644-650.

26. Bergamo, P.; Maurano, F.; Mazzarella, G.I.; Iaquinto, G.; Vocca, I.; Rivelli, A.R.; de Falco, E.; Gianfrani, C.; Rossi, M. Immunological evaluation of the alcohol-soluble protein fraction from gluten-free grains in relation to celiac disease. Mol. Nutr. Food Res. 2011, 55, 1266-1270.

27. Skerritt, J.H.; Devery, J.M.; Penttila, I.A.; LaBrooy, J.T. Cellular and humoral responses in coeliac disease. Protein extracts from different cereals. Clin. Chim. Acta 1991, 204, 109-122.

28. Caja, S.; Mäki, M.; Kaukinen, K.; Lindfors, K. Antibodies in celiac disease: Implications beyond diagnostics. Cell. Mol. Immunol. 2011, 8, 103-109.

29. Accomando, S.; Albino, C.; Montaperto, D.; Amato, G.M.; Corsello, G. Multiple food intolerance or refractory celiac sprue? Dig. Liver Dis. 2006, 38, 784-785. 
30. Calderón de la Barca, A.M.; Cabrera-Chávez, F. No Solo el Gluten Sino Otras Proteínas de la Avena, Maíz y Leche de Vaca Podrían Afectar También a Los Pacientes Celíacos. In Enfermedad Celíaca y Sensibilidad al Gluten no Celiaca; Rodrigo, L., Peña, A.S., Eds.; OmniaScience: Barcelona, Spain, 2013; pp. 89-101.

31. Green, P.H.R.; Cellier, C. Celiac disease. N. Engl. J. Med. 2007, 357, 1731-1743.

32. Nilsen, E.M.; Jahnsen, F.L.; Lundin, K.E.; Johansen, E. Gluten induces an intestinal cytokine response strongly dominated by interferon gamma in patients with celiac disease. Gastroenterology 1998, 115, 551-563.

33. Vader, L.W.; de Ru, A.; van der Wal, Y.; Kooy, Y.M.C.; Benckhuijsen, W.; Mearin, M.L.; Drijfhout, J.W.; van Veelen, P.; Koning, F. Specificity of tissue transglutaminase explains cereal toxicity in celiac disease. J. Exp. Med. 2002, 195, 643-649.

34. Dewar, D.H.; Donelly, S.C.; McLaughlin, S.D.; Johnson, M.W.; Ellis, H.J.; Ciclitira, P.J. Celiac disease: Manegement of persistent symptoms in patients on a gluten-free diet. World J. Gastroenterol. 2012, 18, 1348-1356.

35. Junker, Y.; Zeissig, S.; Seong-Jun, K.; Barisani, D.; Wieser, H.; Leffler, D.A.; Zevallos, V.; Libermann, T.A.; Dillon, S.; Freitag, T.L.; et al. Wheat amylase trypsin inhibitors drive intestinal inflammation via activation of toll-like receptor 4. J. Exp. Med. 2012, 209, 2395-2408.

36. Maiuri, L.; Ciacci, C.; Ricciardelli, I.; Vacca, L.; Raia, V.; Auricchio, S.; Picard, J.; Osman, M.; Quarantino, S.; Londei, M. Association between innate response to gliadin and activation of pathogenic T cells in coeliac disease. Lancet 2003, 362, 30-37.

37. Tortora, R.; Russo, I.; de Palma, G.D.; Luciani, A.; Rispo, A.; Zingone, F.; Iovino, P.; Capone, P.; Ciacci, C. In vitro gliadin challenge: Diagnostic accuracy and utility for the difficult diagnosis of celiac disease. Am. J. Gastroenterol. 2012, 107, 111-117.

38. Drago, S.; El Asmar, R.; di Pierro, M.; Clemente, M.G.; Tripathi, A.; Sapone, A.; Thakar, M.; Iacono, G.; Carroccio, A.; D’Agate, C.; et al. Gliadin, zonulin and gut permeability: Effects on celiac and non-celiac intestinal mucosa and intestinal cell lines. Scand. J. Gastroenterol. 2006, 41, 408-419.

39. Elli, L.; Roncoroni, L.; Hils, M.; Pasternack, R.; Barisani, D.; Terrani, C.; Vaira, V.; Ferrero, S.; Bardella, M.T. Immunological effects of transglutaminase-treated gluten in celiac disease. Hum. Immunol. 2012, 73, 992-997.

40. Zevallos, V.; Ellis, H.J.; Suligoj, T.; Herencia, L.I.; Ciclitira, P.J. Variable activation of immune response by quinoa (Chenopodium quinoa Willd.) prolamins in celiac disease. Am. J. Clin. Nutr. 2012, 96, 337-344.

41. Anderson, R.P.; van Heel, D.A.; Tye-Din, J.A.; Barnardo, M.; Salio, M.; Jewell, D.P.; Hill, A.V.S. T cells in peripheral blood after gluten challenge in coeliac disease. Gut 2005, 54, 1217-1223.

42. Raki, M.; Fallang, L.E.; Brottveit, M.; Bergseng, E.; Quarsten, H.; Lundin, K.E.A.; Sollid, L.M. Tetramer visualization of gut-homing gluten-specific $\mathrm{T}$ cells in the peripheral blood of celiac disease patients. Proc. Natl. Acad. Sci. USA 2007, 104, 2831-2836.

43. Brottveit, M.; Raki, M.; Bergseng, E.; Fallang, L.E.; Simonsen, B.L.S.; Lovik, A.; Larsen, S.; Loberg, E.M.; Jahnsen, F.L.; Sollid, L.M.; et al. Assessing possible celiac disease by an HLA-DQ2-gliadin tetramer test. Am. J. Gastroenterol. 2011, 106, 1318-1324. 
44. Camarca, A.; Radano, G.; di Mase, R.; Terrone, G.; Maurano, F.; Auricchio, S.; Troncone, R.; Greco, L.; Gianfrani, C. Short wheat challenge is a reproducible in-vivo assay to detect immune response to gluten. Clin. Exp. Immunol. 2012, 169, 129-136.

45. Rubio-Tapia, A.; Kyle, R.A.; Kaplan, E.L.; Johnson, D.R.; Page, W.; Erdtmann F.; Brantner, T.L.; Kim, W.R.; Phelps, T.K.; Lahr, B.D.; et al. Increased prevalence and mortality in undiagnosed celiac disease. Gastroenterology 2009, 137, 88-93.

(C) 2013 by the authors; licensee MDPI, Basel, Switzerland. This article is an open access article distributed under the terms and conditions of the Creative Commons Attribution license (http://creativecommons.org/licenses/by/3.0/). 